\title{
Complete Ureteral Duplication: Outcome of Different Surgical Approaches
}

\section{Duplicação Ureteral Completa: Resultado de Diferentes Abordagens Cirúrgicas}

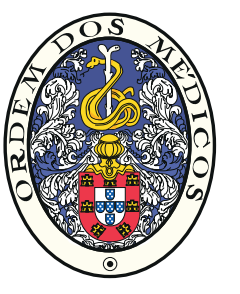

Isabel RODRIGUES $\bowtie{ }^{1}$, José ESTEVÃO-COSTA ${ }^{1,2}$, Ana Catarina FRAGOSO ${ }^{1,2}$

Acta Med Port 2016 Apr;29(4):275-278 - http://dx.doi.org/10.20344/amp.6329

ABSTRACT

Introduction: The surgical management of complete ureteral duplication anomalies is not consensual.

Objective: To characterize the pediatric population who underwent surgery for complete ureteral duplication and assess the outcomes of different approaches.

Material and Methods: Clinical records from patients treated between January 2008 and June 2014 were retrospectively reviewed. Epidemiology, diagnosis, clinical manifestations and surgical procedures were collected and analysed. Ureteral units were divided into two groups: A, with ureterocele; and B, without it.

Results: Forty-one ureteral units from 32 patients with complete duplication underwent surgery. In group $A(n=18)$, the selected primary procedure was: ureterocele punction (12); ureter reimplantation (3); pyelopyelostomy (2); heminephrectomy (1). A reintervention was required in 3 of the 12 units submitted to punction: heminephrectomy (1), ureteroureterostomy (1), and ureteric reimplantation (1). In group B $(n=23)$, STING was performed in 10 units, ureteric reimplantation in 3 , pyelopyelostomy in 3 , ureteroureterostomy in 1 , and heminephrectomy in 6; two cases required reintervention.

Discussion: A conservative primary approach was favoured in cases with ureterocele and/or reflux in hemisystems worth preserving $(53.7 \%)$; it was effective per se in $75 \%(n=9 / 12)$ units in group $A$ and $80 \%(n=8 / 10)$ in group $B$. An ablative primary procedure was adopted in $17 \%(n=7 / 41)$ cases, $5.6 \%$ of group $A(n=1 / 18)$ and $26.1 \%$ of group $B(n=6 / 23)$.

Conclusions: A conservative approach is effective as a primary and isolated procedure in the majority of cases with ureterocele or vesicoureteral reflux. Further studies are needed to establish the advantages over primary invasive or ablative approaches.

Keywords: Nephrectomy; Ureter/abnormalities; Ureter/surgery; Vesico-Ureteral Reflux.

\section{RESUMO}

Introdução: O tratamento cirúrgico das duplicações ureterais completas não é consensual.

Objetivos: Caraterizar a população pediátrica submetida a cirurgia para tratamento de duplicações ureterais completas e avaliar resultados de diferentes abordagens.

Material e Métodos: Processos clínicos de doentes tratados entre janeiro de 2008 e junho de 2014 foram retrospetivamente revistos. Dados acerca de epidemiologia, diagnóstico, manifestações clínicas e procedimentos cirúrgicos foram recolhidos. As unidades ureterais foram divididas em dois grupos: A, com ureterocelo; e B, sem ureterocelo.

Resultados: Quarenta e uma unidades ureterais de 32 doentes com duplicação completa foram intervencionados. No grupo $A$ ( $n=$ 18), o procedimento primário selecionado foi: punção de ureterocelo (12); reimplantação de ureter (3); pielopielostomia (2) e heminefrectomia (1). Foi necessário reintervir em três dos 12 casos submetidos a punção: heminefrectomia (1), ureteroureterostomia (1) e reimplantação (1). No grupo B $(n=23)$, foi efetuado STING em 10 unidades, reimplantação ureteral em três, pielopielostomia em três, ureteroureterostomia em um, e heminefrectomia em seis; dois casos necessitaram de reintervenção.

Discussão: Foi favorecida uma abordagem primária conservadora para tratamento de ureterocelo ou refluxo em hemissistemas a preservar $(53,7 \% ; n=22 / 41)$, tendo sido eficaz per se em $75 \%(n=9 / 12)$ unidades do grupo A e $80 \%(n=8 / 10)$ do grupo B. Uma abordagem ablativa primária foi adotada em $17 \%(n=7 / 14)$ casos, $5,6 \%$ do grupo $A(n=1 / 18)$ e $26,1 \%$ do grupo $B(n=6 / 23)$.

Conclusão: Uma abordagem conservadora é eficaz como procedimento primário isolado na maioria dos casos com ureterocelo ou refluxo. Mais estudos são necessários para estabelecer as suas vantagens sobre abordagens primárias invasivas ou ablativas.

Palavras-chave: Nefrectomia; Refluxo Vesicoureteral; Ureter/anomalias; Ureter/cirurgia.

\section{INTRODUCTION}

Ureteral duplication is a common congenital abnormality of the urogenital tract, and is present in about $0,8 \%$ of the population. ${ }^{1}$ Most of them are incomplete and remain undetected and clinically silent. However, when complete, ureteral duplications may coexist with ectopic ureters or ureteroceles, and manifestations such as vesicoureteral reflux (VUR), obstruction, incontinence or urinary tract infections (UTIs), isolated or in association. Due to kidney dysplasia, present in a non-negligible percentage of cases, a decrease in renal function is common. ${ }^{2-4}$

Nowadays, most cases are suspected during the prenatal period by ultrasonography, which is the firstline exam and cornerstone of diagnosis. Diagnosis requires further anatomic and functional characterization by voiding cystouretrography (VCUG), technecium-99m mercaptoacetyltriglycine (MAG3) renogram, technecium$99 \mathrm{~m}$ dimercaptosuccinic acid (DMSA) renal scan, or magnetic resonance..$^{2,3}$

\footnotetext{
1. Faculty of Medicine. University of Porto. Porto. Portugal.

2. Department of Pediatric Surgery. Centro Hospitalar de S. João. Porto. Portugal.

$\bowtie$ Autor correspondente: Isabel Rodrigues. isabelbastosrodrigues@gmail.com

Recebido: 18 de fevereiro de 2015 - Aceite: 28 de setembro de 2015 | Copyright $\odot$ Ordem dos Médicos 2016
} 
Considering the variable clinical and pathologic spectrum, treatment options should be individualized. As a consequence, standardized decision-making is lacking, and there are still many controversies about the surgical management of complete ureteral duplications. ${ }^{5}$

The purpose of this study was to characterize the pediatric population who underwent surgery for complete ureteral duplication on a tertiary care facility. We also aimed to assess the outcomes of the different surgical approaches, in order to help clarify the therapeutic management of complete ureteral duplications.

\section{MATERIAL AND METHODS}

A retrospective search was performed on the clinical records of Centro Hospitalar de S. João, EPE (CHSJ), in order to identify all pediatric patients (from birth to age 18) who underwent surgery for complete ureteral duplication at the Pediatric Surgery Department between $1^{\text {st }}$ January 2008 and $30^{\text {th }}$ June 2014 . All patients with severe comorbidities such as polymalformative syndromes were excluded. Approval was obtained by CHSJ's Ethics Committee. The search was carried out using the codes of procedures and common manifestations of ureteral duplications ("kidney repairs", "partial nephrectomy", "cystoscopy", "kidney infections", "congenital malformations of the kidney and ureter", "congenital ureterocele", "hydronephrosis").

Medical records were reviewed and data regarding epidemiology, clinical manifestations, diagnosis and surgical procedures was collected. The information was stored and analyzed using IBM SPSS Statistics 22. $P$ values were calculated using Fisher's exact test.

Renal units were divided into two groups, group $A$ (complete duplication with ureterocele) and B (complete duplication without ureterocele). Surgical procedures were divided into conservative (ureterocele punction and STING) or invasive (ureteric reimplantation, derivative anastomosis and heminephrectomy), and into ablative (heminephrectomy) or non-ablative (all others).

Terms defined by Glassberg et $\mathrm{al}^{6}$ were used to define the morphology of the duplicated systems and associated phenomena, while vesicoureteral reflux was graded according to the radiographical grading system proposed by the International Reflux Study. ${ }^{7}$

\section{RESULTS}

Thirty-two patients with complete ureteral duplication were identified. The median age at first intervention was 6.2 months. Seventeen of the 32 patients were female (53.1\%).

Twenty one patients whose ureteral units were included in this study were diagnosed by prenatal ultrasound (65.6\%), and 7 were diagnosed during an investigation for recurrent urinary tract infections $(21.9 \%)$. One patient presented with incontinence, and another had both recurrent UTIs and incontinence. In two cases, there was no available information regarding diagnosis.

A total of 41 ureteral units underwent surgical treatment. An ureterocele was identified on 18 out of the 41 (group A), and their management will be analysed separately from that of the units without ureterocele (group B), and both are outlined on Figure 1.

\section{GROUP A- Ureteral units with ureterocele $(n=18)$}

The ureteroceles were intravesical in 10 cases $(55.6 \%)$ and ectopic in $8(44.4 \%)$. All of these units drained upper poles, and $12(66.7 \%)$ were on the left side.

There was no vesicoureteral reflux in any of these ureteral units, but VUR was present in 2 ipsilateral lower pole ureters and in the contralateral kidney on other 2 cases.

Twelve of these ureteral units underwent a transureteral cystoscopic punction of the ureterocele. The six (33\%) remaining cases were submitted to more invasive procedures: ureteric resection and ureteric reimplantation using the Cohen technique in 3 cases; pyelopyelostomy in 2; and heminephrectomy in 1.

Three of these procedures were carried in an outpatient setting. The median length of hospitalisation was 3 days for cystoscopical procedures and 8.5 days for open ones. The median age at intervention was 2.4 months for cystoscopical interventions and 1 year for the remaining.

Three units that had undergone an ureterocele punction as the primary procedure required reintervention: an ureteroureterostomy in one case, an heminephrectomy in

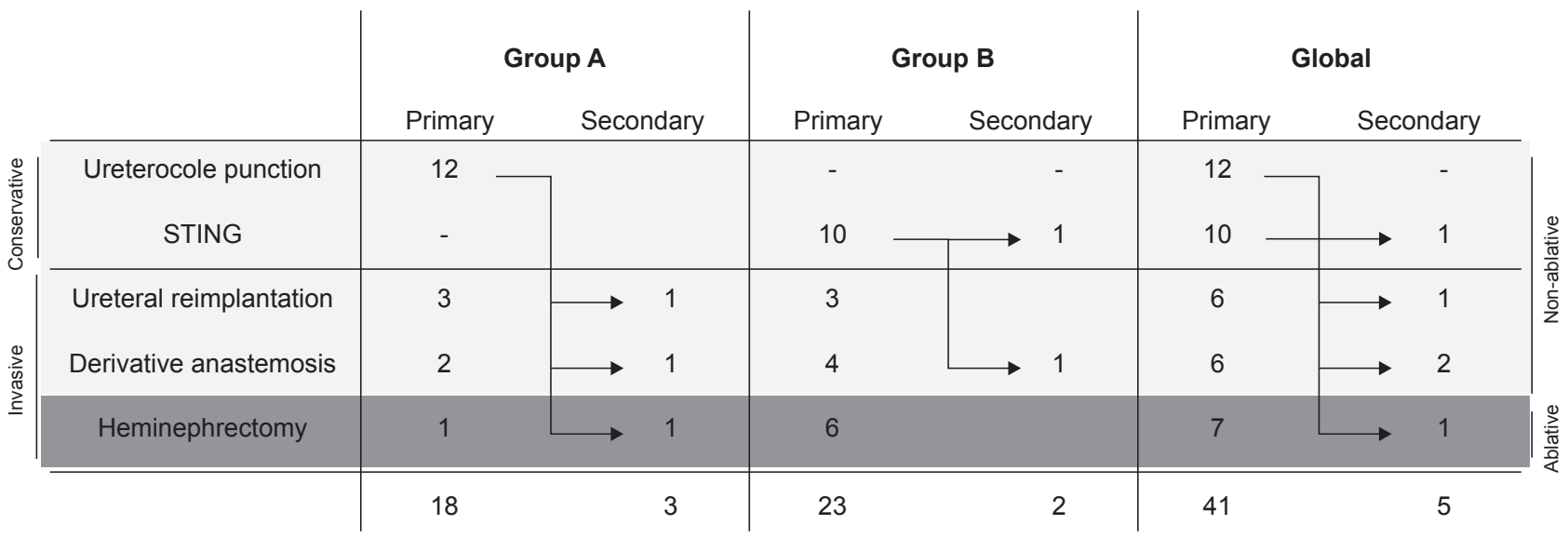

Figure 1 - Primary and secondary surgical procedures in Group A, Group B and Global 
one, and an ureteric resection with reimplantation in one. The three units were ectopic ureteroceles. The second procedure was performed at a median of 44 days after the first one.

\section{GROUP B - Ureteral units without ureterocele $(n=23)$}

In group B, twelve (52.2\%) ureteral units drained upper poles. Sixteen $(69.6 \%)$ of these units were on the left.

Nine of these ureteral units had ectopic insertions (five in the urethra, 3 in the vagina and one in the bladder neck), all of which drained the upper pole of the corresponding kidney.

Vesicoureteral reflux into the intervened hemisystem was identified in 13 of the 23 units. Furthermore, 2 cases had VUR into the other pole of the ipsilateral kidney; VUR into the contralateral kidney was identified in one additional case.

As a primary procedure, the decision fell upon a cystoscopic subureteral injections of hyaluronic acid/ dextranomer polymer (STING) in 10 units. The remaining primary procedures were invasive and/or ablative (heminephrectomy in 6; ureteric reimplantation using the Cohen technique in 3 , pyelopyelostomies in 3 ; and ureteroureterostomy in 1).

Five out of the 23 procedures were performed in an outpatient setting (all STING), and the others had a median hospitalisation of 1 day (when a cystoscopic approach was selected) or 4.5 days (when an open approach was chosen). The median age at first procedure was 2.4 months when cystoscopic, and 1.4 years when open.

A reintervention was required in two ureteral units, which had previously undergone cystoscopic procedures (one secondarily underwent an ureteropyelostomy, and the other a STING). Both had grade $\mathrm{V}$ vesicoureteral reflux, and were reintervened a median of 1.8 years after the first procedure.

\section{DISCUSSION}

Early diagnosis has been associated with a better prognosis in ureteral duplication, since it allows a therapeutic intervention (surgical or conservative) before the onset of UTIs, preventing further impairment of renal function. ${ }^{8}$ In our cohort, an antenatal diagnosis by ultrasound had been made in $65.6 \%$ of patients. This favours an early intervention, a factor that may influence not only the chosen procedure but also the long-term outcome.

According to different studies, several factors may influence the choice of treatment, such as the age, manner of presentation, type of ureterocele, grade of VUR (if present), UTIs, remaining renal function of the affected moiety and preference of the surgeon. ${ }^{5,9}$ The present study corroborated the importance of some of these factors on the choice of a primary procedure, especially the coexisting pathological findings.

An ablative procedure was selected as a primary approach in $17 \%(n=7 / 41)$ cases, which encompassed $5.6 \%(n=1 / 18)$ of the units with ureterocele and $26.1 \%$ ( $n=6 / 23$ ) of the units without it. A non-ablative approach was preferred in $83 \%(n=34 / 41)$ cases, and a second ablative intervention was required in $17.6 \%(n=3 / 17)$ units in group $A$ and $11.8 \%(n=2 / 17)$ in group $B$. The differences between groups $A$ and $B$ were not statistically significant in any of the subgroups.

A primary invasive procedure was preferred in a total of $46.3 \%$ ( $n=19 / 41)$ cases, among which were $33.3 \%$ ( $n=6 / 18)$ of group $A$ and $56.5 \%(n=13 / 23)$ of group $B$. A conservative primary approach was favoured to primarily address the ureterocele and/or VUR in 53.7\% ( $n=22 / 41$ ) cases and was effective per se in $75 \%(n=9 / 12)$ of cases in group $A$ and $80 \%(n=8 / 10)$ in group $B$. However, an invasive secondary procedure was required in $25 \%$ in group $A(n=3 / 12)$ and $20 \%$ in group $B(n=2 / 10)$. Again, the comparison between groups $A$ and $B$ was not statistically significant in any of these.

Several studies have evaluated the outcomes of this type of conservative cystoscopic approach, with satisfying results. Many of them reported a better outcome for intravesical ureteroceles in comparison with ectopic ones following a cystoscopic punction. ${ }^{5}$ Merlini et al proposed general guidelines for management of ureteroceles, in which the main approach for intravesical ureteroceles was an endoscopic puncture (definitive in 77 to $93 \%$ of patients). This contrasts with ectopic ureteroceles, for which other elective approaches are proposed depending on the remaining function and presence of VUR. ${ }^{9} \mathrm{~A}$ consensus regarding treatment of this type of ureterocele has not yet been reached. ${ }^{4}$ Even so, the preoperative determination of the ureterocele location can be misleading, and only an intraoperative evaluation can give definitive information on this matter. Castagnetti et al found incongruences between the two in as many as one fourth of their cases. ${ }^{10}$ Nonetheless, all the reintervened ureteroceles in group $A$ were classified as ectopic, which corroborates the findings of these studies.

When the estimated renal function of the affected moiety is very low, an heminephrectomy is generally preferred. A concern with this approach is the fact that it does not eliminate the ureterocele or correct the VUR, when present, making it possible for the symptoms to persist, a condition that justified a second procedure in 41 to $65 \%$ of patients in some series. ${ }^{11}$ This did not occur in any of the 8 patients who underwent heminephrectomies, both as primary procedure or reintervention. Also, an heminephrectomy is regarded as a manner of avoiding two dreaded complications of a nonfunctioning pole: hypertension and a possible malignant neoplasia stemming from dysplastic tissue. ${ }^{4}$ However, since this relationship with the appearance of malignancies was never proven, ${ }^{12}$ and since this surgery can give rise to complications such as damage to the remaining moiety, more conservative approaches have been gaining support for patients without UTIs, at times even when VUR is present. ${ }^{4,13,14}$

Group B, in which ureterocele was absent, was more heterogeneous. The manifestations and remaining renal function depended on the coexisting findings (such as VUR 
and an ectopic ureter, present in a significant percentage of the patients in this group), which ultimately defined the chosen procedure. As for cases in which uncomplicated VUR is present, Ellerkamp et al postulate that a STING is the gold-standard treatment for VUR up to grade IV. ${ }^{4}$ In fact, VUR was quantified as grade $V$ in both cases of the group that required reintervention. However, a meta-analysis by Routh et al reports a $62 \%$ success rate for STING in children with grade V VUR. ${ }^{15}$ Again, there is no consensus on how to manage these cases, and there are other factors to take into account, such as the age of the patient and parental preference. Also, it has been reported that VUR may subside spontaneously,14 and, in some series, VUR status did not have any role in guiding the selection of the first procedure. ${ }^{10}$

In spite of the evidence supporting all of these facts regarding the surgical management of duplication anomalies, it is important to note that this is still a very controversial issue. A 2010 study by Merguerian et al surveyed Pediatric Urologists in how they would conduct treatment in 3 different hypothetical scenarios of duplex systems, and their responses varied widely. ${ }^{5}$

This study was limited by its retrospective nature. Since the implications of a duplex system vary widely from case to case, a larger number of patients might have allowed us to walk towards a more representative analysis and conclusions.

\section{REFERENCES}

1. Privett J, Jeans $W$, Roylance J. The incidence and importance of renal duplication. Clin Radiol. 1976;27:521-30.

2. Winyard P, Chitty LS. Dysplastic kidneys. Semin Fetal Neonatal Med. 2008;13:142-51.

3. Ubetagoyena Arrieta M, Sarasqueta Eizaguirre C, Arruebarrena Lizarraga $\mathrm{D}$, Areses Trapote $\mathrm{R}$. Duplicaciones del tracto urinario. An Pediatr. 2012;77:261-6.

4. Ellerkamp V, Szavay P, Luithle T, Schafer JF, Amon O, Fuchs J. Singlestage surgical approach in complicated paediatric ureteral duplication: surgical and functional outcome. Pediatr Surg Int. 2014;30:99-105.

5. Merguerian PA, Taenzer A, Knoerlein K, McQuiston L, Herz D. Variation in management of duplex system intravesical ureteroceles: a survey of pediatric urologists. J Urol. 2010;184:1625-30.

6. Glassberg K, Braren V, Duckett J, Jacobs E, King L, Lebowitz R, et al. Suggested terminology for duplex systems, ectopic ureters and ureteroceles. J Urol. 1984;132:1153-4.

7. Lebowitz R, Olbing H, Parkkulainen K, Smellie J, Tamminen-Möbius T. International system of radiographic grading of vesicoureteric reflux. International Reflux Study in Children. Pediatr Radiol. 1985;15:105-9.

8. Adiego B, Martinez-Ten P, Perez-Pedregosa J, Illescas T, Barron E, Wong A, et al. Antenatally Diagnosed Renal Duplex Anomalies. J Ultra-

\section{CONCLUSIONS}

In our cohort, a conservative approach was effective as a primary and isolated procedure in the majority of cases with ureterocele or VUR.

Given the diversity of factors to consider when selecting the most appropriate surgical procedure, a thorough characterization of coexisting findings should be made, particularly when grading VUR and determining the location of ureteroceles and insertion of ectopic ureters.

A prospective study with a larger sample and more comprehensive clinical information is warranted to find out a consensus regarding the management of this urogenital tract malformation.

\section{PROTECTION OF HUMANS AND ANIMALS}

The authors declare that the procedures were followed according to the regulations established by the Clinical Research and Ethics Committee and to the Helsinki Declaration of the World Medical Association.

\section{DATA CONFIDENTIALITY}

The authors declare having followed the protocols in use at their working center regarding patient's data publication.

\section{CONFLICTS OF INTEREST}

The authors declare that there are no conflicts of interest.

\section{FUNDING SOURCES}

No subsidies or grants contributed to this work.

sound Med. 2011;30:809-15.

9. Merlini E, Lelli Chiesa P. Obstructive ureterocele-an ongoing challenge. World J Urol. 2004;22:107-14

10. Castagnetti M, Vidal E, Burei M, Zucchetta P, Murer L, Rigamonti W. Duplex system ureterocele in infants: should we reconsider the indications for secondary surgery after endoscopic puncture or partial nephrectomy? J Pediatr Urol. 2013;9:11-6.

11. Gran CD, Kropp BP, Cheng EY, Kropp KA. Primary lower urinary tract reconstruction for nonfunctioning renal moieties associated with obstructing ureteroceles. J Urol. 2005;173:198-201.

12. Husmann D. Renal Dysplasia: The Risks and Consequences of Leaving Dysplastic Tissue In Situ. Urology. 1998;52:533.

13. Pohl HG. Recent advances in the management of ureteroceles in infants and children: why less may be more. Curr Opin Urol. 2011;21:322-7.

14. Adorisio O, Elia A, Landi L, Taverna M, Malvasio V, Danti A. Effectiveness of primary endoscopic incision in treatment of ectopic ureterocele associated with duplex system. Urology. 2011;77:191-4.

15. Routh JC, Inman BA, Reinberg Y. Dextranomer/hyaluronic acid for pediatric vesicoureteral reflux: systematic review. Pediatrics. 2010;125:1010- 